\title{
CURRENT STATUS OF AFLATOXIN AND ITS CONTROL IN THAILAND
}

\author{
Maitree SUTTAJIT \\ Department of Biochemistry, Faculty of Medicine, \\ Chiang Mai University, Chiang Mai 50200, Thailand. \\ Fax.56-217-144 Email: mdbci002@chiangmai.ac.thSchool of Public Health, \\ Sun Yat-Sen University of Medical Sciences, Guangzhou, 510089, China
}

\section{INTRODUCTION}

Aflatoxins (AF) are fungal metabolites produced by Aspergillus flavus and Aspergillus parasiticus. One of aflatoxins, $\mathrm{AFB}_{1}$, is the most potent natural mutagen and hepatocarcinogen (Suttajit). The prevention and control of its health hazard and risk have been strongly encouraged. In Thailand, AF has been monitored and found to be commonly contaminated in daily foodstuffs, mixed feeds, including peanut, corn, spices, rice and noodle, etc. (suttajit,Glinsukon at al.). This paper will briefly review on-going research activities about AF, especially its human exposure, health risk and some research progress in Thailand. A recent national policy and strategy by the Thai Government to control and regulate aflatoxin problem in commercial products including peanut, maize and milk will be also mentioned.

\section{Aflatoxins and Health Concern in Thailand}

The exposure of AF in Thai commercial foods was found to be varying in different parts of the country. The incidence of liver cancer is the highest one in Thailand: 40.5 per $10^{5}$ population in males and 16.3 in females and more than a half of the case is hepatocellular carcinoma (HCC) (Vatnasapt). Aflatoxin is generally considered to be an important cause of liver cancer among Thais (Wild $e t$ al.). By direct measurement of $\mathrm{AFB}_{1}$-albumin adduct in serum as a biomarker, the correlation study and a case-control study was, however, still limited to explain the risk of HCC by AF consumption (Srivatanakul et al). The adduct was shown to be significantly higher in vegetarians than non-vegetarians (Vinitketkamnuan et al). This could explain and is consistent with that the urinary excretion of $\mathrm{AF}$ and mutagenic compounds after animal feeding was distinctly higher in experimental rats than the controls; and this same pattern could be found in vegetarians who usaully consume more AFcontaminated peanut than nonvegetarians (Suttajit,1987,Choketaworn). The epidemiological studies by measuring AF exposure assessment and p53 gene mutations from $G$ to $T$ at codon 249 are all suggestive of a limited importance of $\mathrm{AF}$ as an etiological factor of HCC in Thailand compared to southern China and Africa (Hollstein). Other known and potential hepatocarcinogens and tumor promoters such as dietary $\mathrm{N}$-nitroso compounds, hapatitis B virus, alcohol consumption, tobacco smoking hepatotoxic drugs and parasitic infecions in the country should be also also brought to consideration.

\section{Aflatoxins in Peanut, Corn, Spices and Feedstuffs}

Thailand is in a tropical zone with much rains and high humidity which are suitable for rapid growth of fungi including Aspergillus. AF mainly as $\mathrm{AFB}_{1}$ are frequently observed in agricutlural commodity products which are good substrates, especially peanut, corn, copra, dried plants, and shrimp. The presence of $\mathrm{AF}$ in corn and peanut a can be chemically destroyed upto $80 \%$ by $3-5 \%$ ammoniunm bicarbonate solution. The ammoniated products are no longer mutugenic and should be safe for consumpion (Suttajit,1987). commercial products a varying types of those agricultural products and mixed feeds for animals has been analysed, monitored and become increasingly awared by Thai government authorities (Table 1).

It is evident that peanut, corn, their products and mixed feeds are highly contaminated with AF. AF higher than the safely level of $20 \mathrm{ppb}$ for human consumption are found in several food sample and at levels higher 50-100 ppb for feed samples. Without a

Correspondence : Maitree SUTTAJIT

Vol. 23 Suppl. II 
control, Thai people could be exposed to AF directly from dietary products or indirectly from animal products. Therefore, such the AF contamination in Thailand has to be reduced, removed, detoxified, and controlled . All these measures could be done nationwide by more research, education, personnel training and strict regulation.

\section{AF Could Be Found in Noodle}

Noodle soup is a popular daily foods eaten by Thais. Its ingredients are mainly white rice noodle, certain meat, seasonings, chilli, ground-roasted peanut, bean sprout and fresh vegetables. Noodles are usually freshly, daily made in home industries and each lot of noodle is usaully sold in one day to shops and customers. Before marketing, noodles are always coated with raw peanut oil, palm oil or other seed oils by noodle machine oil to reduce noodle stickiness.
Since crude peanut oil always has AF as a contaminant. It will be interesting and useful to find out whether the commercial noodle will be contaminated with $\mathrm{AF}$ which is contained in peanut oil or other oils.

Ten fresh samples of commercial noodle were bought in Chiang Mai markets and determined for aflatoxin by TLC and fluorometry. AF is measured in the coating oil separated from fresh noodle which was averaged about $9-10 \%$ by weight of wet noodle. The AF quantitation was performed before quick heating in boiling water $\left(100^{\circ} \mathrm{C}, 15 \mathrm{sec}\right.$.) and after heating which is similar to the way of noodle cooking in noodle shops and restaurants. The \% recovery test for AF in this oil was 86.03. The result showed that those fresh noodle samples $(5 / 10)$ contained AFB। of 20.24 $\pm 41.16 \mathrm{ppb}$ before rapid heating and of $15.75 \pm$ $37.9 \mathrm{ppb}$ after rapid heating. The heating could reduce AF only $22 \%$. The content of AF in the oil samples

Table 1. Presence of Aflatoxins in Penut/Corn Products and Feeds Reported in Thailand.

\begin{tabular}{|c|c|c|}
\hline Samples & $\% \mathrm{AFB}_{1}$ positive & References \\
\hline \multicolumn{3}{|l|}{ Foodstuffs: } \\
\hline Peanut products, corn, plant & 30 & Shank. et al 1972 \\
\hline seeds, chilli pepper $(\mathrm{N}=2000)$ & 30 & Shank. et al 1972 \\
\hline Peanut $(\mathrm{N}=121)$ & $20.6 * *$ & Glinsukon, et al 1976 \\
\hline Peanut, ground \& roasted & $75.9 *$ & Thasnakom, et al 1977 \\
\hline Peanut, ground \& roasted $(\mathrm{N}=34)$ & $96 * *$ & Suttajit, et al 1977 \\
\hline Peanut oil, crude $(\mathrm{N}=10)$ & $100 * *$ & Suttajit, et al 1977 \\
\hline Peanut butter and fermented rice $(\mathrm{N}=120)$ & $5-10$ & Sripathomswat, et al 1981 \\
\hline Peanut products $(\mathrm{N}=24)$ & $46.4^{* *}$ & Limtrakul, et al 1994 \\
\hline Peanut products $(\mathrm{N}=33)$ & $97 * *$ & Som-Ngern, \& Suttajit, \\
\hline Corn seeds $(\mathrm{N}=24)$ & $66.7 * *$ & Limtrakul, et al 1994 \\
\hline Rice grains, uncooked $(\mathrm{N}=20)$ & $63^{* *}$ & Som-Ngem, \& Suttajit, \\
\hline Peanut oil, crude $(\mathrm{N}=4)$ & $100 * *$ & Kachareon, et al 1997 \\
\hline \multicolumn{3}{|l|}{ Feedstuffs: } \\
\hline Animal feeds $(\mathrm{N}=24)$ & $88 * * *$ & Suttajit, et al 1987 \\
\hline Mixed feeds $(\mathrm{N}=185)$ & $72 *$ & Karunyavanich et al, 1983 \\
\hline Corn used as animal feeds $(\mathrm{N}=224)$ & $82.6^{* * *}$ & Kachareon, et al 1997 \\
\hline Peanut meal used as animal feeds $(\mathrm{N}=26)$ & $100 * * *$ & Kachareon, et al 1997 \\
\hline
\end{tabular}

*AFBI concentrations analysed are higher than $10 \mathrm{ppb}$.

$* * A F B$, levels are higher than the permitted level of 20 ppb for human consumption.

$* * * A F B$ l levels are higher than the permitted level of 100 ppb for com and some mixed feeds. 
(9/10) isolated from noodles was significantly high as $343.4 \pm 298.2 \mathrm{ppb}$.

This rather high contamination of AF in noodle daily consumed by all Thais is another health-risk problem to be solved. A project to solve this toxin contamination is now being studied for a risk assessement and being investigated for further removal, prevention and control.

\section{Development of Methodology}

The contamination of AF is mainly investigated in: peanuts as used in different varieties of Thai foods and snacks; raw peanut oil used for coating chinese noodle; maize for domestic animal feeds/export; and AFM $_{1}$ found in commercial powdered and liquid cow milk.

Qualitative and quantitative analysis of AF are generally carried out in certain Thai laboratories by using different methods: Minicolumn, TLC, HPLC, immunoassay and ELISA. However, the detection methods for AF is time consuming, costly and needs well-trained laboratory personnels, therefore, more convenient but less expensive technic is essentially needed. ELISA kits using polyclonal/monoclonal antibodies have been imported for more convenient field test but limitedly used in research laboratories. We, since 1991, have succesfully developed a simpler methods for rapid, sensitive and specific test mainly for $\mathrm{AFB}_{1}$ and the test can somewhat cross reacts with AFG..(Limtrakul et al.)

Eight stable hybridoma cells secreting IgG anti $\mathrm{AFB}_{1} \mathrm{mAbs}$ were produced. One-step methanol extraction of AF from samples of peanut and corn was done and by using an anti-AFB $1 \mathrm{mAb}$ and $\mathrm{AFB}_{1-}$ conjugated with horseradish peroxidase could be established. This successful immunoenzymeassay obtained has been introduced, in a trial phase, as the AF test reagent kit to end-users including trained corn/penut farmers, feed factories and importing companies.

\section{National Policy for Regulation and Control by Standardization}

Recently, a committee organized by the Industrial Standard Control Office, universities, government institutions and private sectors have been jointly working on how to solve the problem and how to decontaminate and control aflatoxin found in foods, milk and feeds by standardization.

Public education and training the personnels have been supported and encouraged. The commer- cial production of AF-safe food products and feeds are being attempted. The 3-year project supported by the Government and the working cooperation between those involved in laboratories, farming, food/feed factories and consumers are being actively carried out.

It is our goal and plan that the AF contamination problem in dietary products and animal feeds and health risk will be reduced and solved in the near future. Hopefully, if no other factors much involved, the incidence of liver cancer and diseases among Thai population would be subsequently somewhat decreased.

\section{REFERENCES}

Choketaworn, N. and Suttajit, M. Urinary excretion of aflatoxin and its metabolites in rats orally administered aflatoxin $\mathrm{B}_{1}$, Thai J. Toxicology, 2, 1986, 21-32.

Glinsukon, T., Thamavit, W., Ruchiwat, M., 1976. Studies on the population of toxigenic fungi in market foods and foodstuffs 1 . Mycoflora contamination. Sci. Soc. Thailand, 2, 1976, 176.

Hollstein, M.C., Wild, C.P., Blecher, F., Chutimataewin, S., Harris, C.C., Srivatanakul, P. and Montesano, R. p53 mutations and aflatoxin $\mathrm{B}_{1}$ exposure in hepatocellular carcinoma patients from Thailand. Int. J. Cancer, 53, 1993, 51-55.

Kachareon, Y., et. al. (personal communication).

Limtrakul, P., Sapyen, D., Puttanont, P., Srichuwong, S., Vanittanakom, N., Suttajit, M. Determination of aflatoxin $\mathrm{B}_{1}$ in corn seeds by home-made ELISA reagents compared to commercial ELISA tests and thin-layer chromatography. Thai J. Toxicology, 10, 1-6, 1994.

Som-Ngern. S., and Suttajit, M., Aflatoxin B contamination in rice noodle. (To be published.)

Srivatanakul, P.,Parkin, D.M., Jiang, Y.-Z., Khlat, M., Kao-Ian, U.T., Sontipong, S. and Wild, C. The role of infection by Opisthorchis viverrini, hapatitis B virus and aflatoxin exposure in the etiology of liver cancer in Thailand: a correlation study. Cancer, 68, 1991, 2411-2417.

Suttajit, M., Mycotoxins and Carcinogenesis. XVI International Cancer Congress. New Delhi, India 30st Oct.-5 Nov.1994, 437-540.

Suttajit, M., Environmental Monitoring of Aflatoxins and Other Mutagens in Thailand. Current Status of Cancer Research in Asia, the Middle East and Other Countries, edited by Wada, T., Aoki, K, and Yahci, A., The University of Nagoya Press 
176 The Journal of Toxicological Sciences, Vol.23, Supplement II , 173-176, 1998

Proccedings of the 1st ASIATOX Conference, June 29-July 2, 1997, Yokohama, Japan

1987, $201-214$.

Vatnasapt, V. Martin, N., Sriplung H., Chidavijak, K., Sontipong, S., Sriamporn, S., Parkin, D.M., Ferlay, J., IARC Technical Report No.16: Cancer in Thailand 1988-1991. Lyon 1993, 64-65.

Vinitketkamnuan, U., et al. Aflatoxin-albumin adduct in vegetarians and nonvegetarians. (To be published and personal communication).
Wild, C.P., Jansen, L.A.M., Cova, L. and Montesano, R. Molecular dosimetry of aflatoxin exposure: contribution to understanding the multifactorial aetiopathogenesis of primary hepatocellular carcinoma (PHC) with particular reference to hepatitis B virus (HBV). Environ. Hlth. Persp., 99, 1993,115-122. 